2016-04-30

\title{
Design, disability and the planning challenge: the reality of living with severely disabled children
}

\section{ESSEX, Stephen}

http://hdl.handle.net/10026.1/4891

\subsection{0/02697459.2016.1174974 \\ Planning Practice and Research \\ Informa UK Limited}

All content in PEARL is protected by copyright law. Author manuscripts are made available in accordance with publisher policies. Please cite only the published version using the details provided on the item record or document. In the absence of an open licence (e.g. Creative Commons), permissions for further reuse of content should be sought from the publisher or author. 
STAPLES, J. \& ESSEX, S.J. (2016) Design, disability and the planning challenge: the reality of living with severely disabled children, Planning Practice and Research, 31 (3), pp.327-346. http://dx.doi.org/10.1080/02697459.2016.1174974

Design, Disability and the Planning Challenge: The Reality of Living with Severely Disabled Children

Jamie Staples,

Planning, Advisory and Compliance Service Business Manager,

Buckingham County Council,

Walton Street,

Aylesbury,

Bucks, HP20 1UA.

Tel: +44 (0)1296-387756

Email: jstaples@buckscc.gov.uk

Dr Stephen Essex,

School of Geography, Earth and Environmental Sciences,

Plymouth University,

Drake Circus, Plymouth, PL8 4AA, UK.

Tel: +44 (0)1752-585980

Fax: +44 (0)1752-584710

Email : stephen.essex@plymouth.ac.uk

(Corresponding author)

\section{Acknowledgements}

The authors would like to thank Professor Mark Brayshay and Dr Stephanie Lavau for their constructive comments on previous drafts of this paper. 
Design, Disability and the Planning Challenge: The Reality of Living with Severely Disabled Children

\begin{abstract}
This paper investigates the effects of the speculative and standardised house building model dominant in the UK on the residential experience of families with severely disabled children and evaluates the barriers to the provision of inclusive accommodation through the planning and development process. Unlike previous studies on the theme, this paper draws together, compares and contrasts, within one location, the experiences of families that include severely disabled members, local planners and housing developers. The results indicate that, as a result of the deficiencies of mainstream housing design and delivery, real and substantial stress can be created for families with disabled children. Moreover, it was found that institutional and attitudinal inertia restricts communication between developers and planners in responding to the needs of these families. It is argued that evidence based on experiential knowledge of the needs of disabled groups is a critical first step in meeting their requirements for appropriately designed housing.
\end{abstract}

KEYWORDS: planning; housing development and disability; physical spaces in buildings; behaviour and space. 


\section{Design, Disability and the Planning Challenge: The Reality of Living with}

Severely Disabled Children

\section{Introduction}

One of the main purposes of planning is to improve places for the benefit of human health and activity, yet arguably the housing needs of all parts of society, such as the disabled, are still not fully addressed in the development process. Driven by speculative and standardised provision for the mass market, volume house builders create dwelling spaces for a standard type of occupant who is able-bodied and cognitively unimpaired and few make any provision for the requirements of the disabled population (Burns, 2004; Imrie, 2004a and b; Young, 1990). As a result, Imrie (1996, p.24) has argued that disabled groups experience 'design apartheid', whereby the form of the built environment constrains, channels or denies their use and movement in that setting, which has an adverse impact on their dignity, privacy and opportunity for self-determination (Gathorne-Hardy, 1999). The house as a built form illustrates the way in which bodies are disabled through socio-cultural norms and that the planning and development process can act as a mechanism to reproduce dominant social relations (Burns, 2004). Even within the emerging building controls for disability, the standards have tended to be formulated selectively around the needs of adults rather than those for other groups, such as children (Milner and Madigan, 2004). Consequently, the experience of families with disabled children in mainstream housing can be particularly acute, with serious implications for the overall quality of life of the whole family (Pyer, et al., 2010).

While there has been considerable research into the effects of mainstream housing accommodation on families with severely disabled children (Beresford, 2006; 
Beresford and Rhodes, 2008; Oldman and Beresford, 2000; Oldman and Beresford, 2010), the aim and original contribution of this paper was to also evaluate the barriers to providing more inclusive residential accommodation for this group through the planning and development process. The objectives of this study were three-fold. The first objective was to assess the effects of living in mainstream housing accommodation for families with severely disabled children, and to identify the house design elements that would improve the living conditions for these families. The second objective attempted to gauge the attitudes of major developers to the identified house design elements, with particular reference to potential barriers to implementation, economic viability and deliverability. The third objective was to assess the appropriateness of local authority policy responses and planning decisions pertaining to the provision of inclusive residential accommodation for families with severely disabled children. Unfortunately, no past authors have drawn together the contrasting experiences and degree of collaboration between the three key stakeholders: the families, the planners and the developers in one specific area. Such an omission provides a clear justification for the present paper and offers new perspectives for policy formulation.

\section{Disability and housing provision}

According to statutory legislation, the definition of disability states that a person is disabled if they have 'a physical or mental impairment which has a substantial and long-term adverse effect on his ability to carry out normal day-to-day activities'

(Disability Discrimination Act, 1995, Section 1.1; Disability Discrimination Act, 2005; Equality Act, 2010). Article 19 (a) of the United Nations Convention of the Rights of Persons with Disabilities states that 'Persons with disabilities have the 
opportunity to choose their place of residence and where and with whom they live on an equal basis with others and are not obliged to live in a particular living arrangements' (UN, 2008). Article 28 (1) goes further by stating that disabled people and their families have a right to an adequate standard of living, which includes housing, and to the continuous improvement of living conditions. The implication for planning and development infers that there is a duty for housing developments to include a choice of adequate accommodation specifically for disabled groups. The medical model of disability, with the perspective that people are disabled by physical and cognitive impediments which can be treated by medical interventions and technologies, no longer represents an adequate response. Instead, the social model of disability, whereby disability is recognised to result from structural barriers and attitudes, which can be removed or ameliorated through inclusive or universal housing design, is emergent and creates an important role for planning (Imrie, 2012; Clarkson and Coleman, 2010). The process might be achieved through user involvement in shaping its integral design of properties, the development and application of new technologies and techniques, or flexibility in the layout of the property through overall floor space dimensions stipulated in planning regulations or negotiations (Imrie, 2012). In some parts of Europe, such as Denmark, Sweden, Norway and The Netherlands, all new dwellings must meet access standards for disabled people (known as 'mainstreaming'). Elsewhere, such as in Austria, Germany, Portugal, Luxembourg and the UK, exclusive legislation sets standards for certain categories of users (such as wheelchair users) or there is a progressive approach, as in Italy, where increasing degrees of accessibility and adaptability are stipulated for different building types or users (Nielsen and Ambrose, 1999; Madeddu, et al., 2015). 
The ability of the planning and development process in the UK to respond fully to this agenda is, however, influenced by a cocktail of circumstances. The dominant model of housing delivery and domestic house design in the UK is driven by speculative development by a small number of high volume house builders. Inevitably, developers respond primarily to the commercial imperative to produce a return of 20 30 per cent on their fixed investment, which encourages a business model underpinned by cost minimisation achieved through standardisation. The major house builders tend to adopt a portfolio of proven design and house types to achieve economies of scale in the cost of design and building materials; to establish quality assurance guarantees for those materials from a trustworthy supply chain; and to ensure reliability in terms of 'buildability', estimated costs and construction schedules (Hooper and Nicol, 1999). While these standard house-types are developed in constant iterative consultation with sales, marketing and customers (Hooper and Nicol, 1999), customisation is discouraged because of its detrimental effect on profit margins, construction schedules and ultimately the marketability of a property at resale (Barlow and Ozaki, 2003). For this reason, customisation has been limited to choices in fixtures and fittings, rather than any flexibility in design or layout (Hooper, 2002). The dominant competitive position of the house builders means that the market has little choice but to pay the prices determined by land and construction costs together with expected profits. The stimulus for product and process innovation, which is common in other consumer goods to reduce prices, is much weaker in the house building sector (Barlow and Ozaki, 2003).

The spatial organisation and architectural composition of dwelling spaces under this model has inevitably been shaped by the requirements of the dominant market, 
usually regarded as a 'biological-type' of physically fit and able-bodied people without bodily impairment (Burns, 2004; Imrie, 2004a and b; Young, 1990) and designed and delivered by a range of professional expertise whose practices have become institutionalised largely by able-bodied groups (Gathorne-Hardy, 1999). In this regard, disabled people have been 'designed out' of the process and house builders often treat disabled people as 'invisible' and illegitimate consumers (Imrie, 2004a, p.688). Often adaptable homes carry a negative connotation and are felt to be problematic in terms of resale marketability (Hooper and Nicol, 1999). Consequently, the effects of such 'thoughtless design' mean that disabled people inhabit 'distorted spaces' (Gleeson, 1999).

Planning is also implicated in the production of speculative housing in that constraints on the release of building land and the long lead-times for gaining planning permission have been argued to modify the behaviour of house builders. Their business models have tended to focus on the acquisition and management of land rather than in house building itself (FTI Consulting, 2012). Within the house building sector, the fundamental barrier to greater diversity in housing types are considered to be the rigid prescriptions of local authorities in planning and design guidelines (Barlow and Ozaki, 2003). However, the ability of the planning system to alter significantly the directional thrust of market forces is constrained. The domestic space standards laid down in the UK in 1961 by Sir Parker Morris were removed in the Local Government, Planning and Land Act of 1980 which was informed by the prevailing political ideology that the market would provide the right type and size of homes (RIBA, 2011), although some local authorities have imposed housing standards through local planning policies (Supplementary Planning Documents). Pre- 
application consultations, Section 106 obligations and Design and Access Statements can raise the profile of disabled needs, but it is market forces and economic viability which ultimately determine the extent of the concessions that developers are willing to accept as part of the development management system and process.

Unlike most other European countries, therefore, the UK does not have planning and building regulations that stipulate space standards or the size of habitable rooms (HATC Ltd., 2006; Gallent, et al., 2010; Manuela, et al., 2015). In the circumstances of a limited land supply, any increase in space standards is likely to raise the price of property and/or reduce the ability of local planning authorities to negotiate development on 'risky' sites. Consequently, the UK now possesses amongst the smallest homes in Europe which constrains the ability of the housing stock to accommodate the needs of disabled people. In 2005, the average dwelling size in the UK was $87 \mathrm{~m}^{2}$, with an average room size of $18.5 \mathrm{~m}^{2}$. In comparison, dwellings in Denmark had an average floorspace of $113 \mathrm{~m}^{2}$ (ie. +29.9 per cent of the UK mean) and an average room size of $29.7 \mathrm{~m}^{2}(+60.5$ per cent). Average house sizes in the USA and Australia were $215 \mathrm{~m}^{2}$ (ie. +149.4 per cent) and $227.6 \mathrm{~m}^{2}$ (ie. +161.6 per cent) respectively (Williams, 2009, p. S85). While small average room sizes affects all household groups in the UK, the impact on those with disabled members are much more acute.

Increasing awareness of the needs of different 'bodies' in the housing system, together with a central government commitment to an inclusive society, have encouraged the introduction of statutory and regulatory controls on housing standards, including building control regulations. In 1999, Part M of the UK Building Regulations required 
that all new private housing for sale should be constructed to minimum standards of accessible design, namely that properties were 'visitable' by wheelchair users (involving a level entrance, circulation space and WC provision wide enough to allow wheelchair access on the ground floor) (Milner and Madigan, 2004). In 2006, all planning applications were to be accompanied by a Design and Access Statement requiring an explanation of how a proposed development was suitable for a site and demonstrate how it can be accessed by prospective users on equal terms, regardless of age, disability, ethnicity or social grouping. In 2008, the Lifetime Homes standard required all newly constructed dwellings supplied by the private sector to meet 20 design features to enable properties to be 'visitable' and adaptable over the lifecycle of a family ${ }^{1}$. These changes began to illustrate to house builders that flexible housing design could be affordable and attractive in the market place (Milner and Madigan, 2004).

While the emergence of standards-led measures have raised the profile of housing needs for disabled groups, and might be perceived as an evolutionary 'staging post' on the road towards a greater objective (Harrison, 2004), there still remain considerable inequalities in the planning, building control and development process. First, a standards-led approach rarely encourages designers and/or builders to exceed minimum building standards, which means that the 'only-just-acceptable-solution' is often taken as the optimal or only outcome (Imrie, 2006). There has been no fundamental rethink of the standard layout and design of dwellings which might provide the quality of accommodation that disabled people require, such as the use of flexible features (demountable walls), smart technologies or the design of multi-

\footnotetext{
${ }^{1}$ Revised in 2010 to cover 16 design features (see http://www.lifetimehomes.org.uk/pages/reviseddesign-criteria.html).
} 
functional rooms with integrated elements (bathing and sleeping facilities) (Imrie, 2006).

Second, the standards do not apply to all features of a house, so often fail to make the whole property accessible. The focus on 'visitability' in the Building Regulations allows for the occasional visit from a wheelchair user, but does not serve a disabled person living in the property on a permanent basis (Milner and Madigan, 2004). Third, the standards are reductionist in tending to define disability primarily in terms of wheelchair users, and those with hearing and/or sight impairment (Harrison, 2004). Other disabilities, therefore, are often not accommodated. Stereotyped assumptions of disabled people are made rather than understanding impairment as a myriad of possible and often changing bodily conditions (Milner and Madigan, 2004).

Fourth, the standards are not multi-generational having been founded on the needs of groups ranging from early adulthood to old age, rather than the requirements of children (Milner and Madigan, 2004). These inadequacies in the design of dwellings have major implications for the lives and well-being of disabled groups. In these terms, the standards do not challenge the social relations of the building industry, nor do they seek to change the ways in which builders operate (Imrie, 2006). It has been argued on many occasions that house builders need to gain a better understanding of the needs of disabled people based on 'real life' experience rather than partial assumptions (Burns, 2004).

For the purpose of this study, the focus was on the housing needs of families with disabled children. The Office for National Statistics (ONS) Survey of British 
Households (2012) suggests that the fastest growth in numbers of disabled people since 1975 has been in children. Approximately 200 babies are born with a cognitive impairment every week in the UK. There are 770,000 disabled children under the age of 16 in the UK, which equates to one child in twenty (Care Quality Commission, 2012, p.6). A range of physical and cognitive impairments affecting children were included in this research (see Table 1). These conditions had potential implications for the design and space standards of residential accommodation. The care of physical impairments requires better space standards for medical equipment, lifts, ramps and storage, while the mitigation of cognitive impairments, which might manifest itself in unusual patterns of thought and behaviour, can require attention to internal layout, safety, sound proofing and even levels of natural daylight and neutral colour schemes to control stress. The availability of segregated personal and supportive space for other family members can be equally important to ensure the well-being of the whole household. Without consideration of these conditions, mainstream housing design can create difficulties in caring for disabled children on a day-to-day basis, through inadequate and non-functional rooms to meet the carer's management of disability; a lack of space for equipment, storage and the rest of the family; poor safety features on fixtures and fittings; and an inability to move about the property because of stairs.

Families with disabled children are more likely to live in unsuitable housing than families with non-disabled children (Beresford and Rhodes, 2008). Beresford (2006) found that of those children who required specially adapted homes, 53 per cent were living in unsuitable accommodation (in comparison with only 20 per cent of people aged 65 or over). Standard domestic environments were implicated in poor physical and mental outcomes, not only for the disabled child, but also for the whole family 
(Beresford and Oldman, 2010). In many respects, these families might be described as living in 'unhealthy' houses (Oldman and Beresford, 2010, p.431).

\section{Torbay Study Area}

The benign and health-giving properties of coastal environments have been the raison d'être for the formation and growth of seaside resorts in Britain since the eighteenth century, especially in attracting disabled groups (drawn, in some cases, by relatively cheaper housing from the stock of surplus tourist accommodation) and wealthy retired migrants (who favour the premium housing market) (House of Commons, 2007; Rickey and Houghton, 2009). Evidence from the House of Commons Select Committee (2007) found that the levels of those who claimed income incapacity benefit, special disability allowance or income support for disability has increased six times as much in coastal towns as the national average between 1997 and 2007. As one of the largest seaside resorts in the UK, Torbay was selected as an appropriate case study area.

In 2011, Torbay's population totalled 130,959 , and included approximately 15,500 (11.5 per cent) experiencing long-term health problems or a disability that limited their day-to-day activities (ONS, 2012). Included in the total population were 29,500 children and young people, of whom about 354 (1.2 per cent) had (an) impairment(s) that severely impacted on their own quality of life as well as that of their carers and other family members (ONS, 2012). In March, 2013, the Torbay Children's Integrated Service (CIS) had a case load of approximately 500 children requiring their support. However, some children were receiving services across Health, Education and Social Care, so are likely to have been double or triple counted. Conditions ranged from 
those with dyspraxia, who may receive some one-off occupational therapy interventions, to children with profound and multiple disabilities.

Although Torbay increased its housing supply in 2010-11, the current rate of construction is unlikely to achieve the housing needs and targets set. The Local Plan policy (Torbay Council, 2014, Policy H6, pp.136-138) states that developments of over 50 homes must provide five per cent of homes to lifetime standards, which specifies that these properties are capable of adaptation. Given that these figures equate to eight Lifetime standard homes per year, it could be inferred that the policy target will not meet the current or future levels of disabled populations in Torbay. The low supply numbers also indicate that it will be difficult for families with disabled children to find adequate and affordable accommodation.

\section{Methodology}

Four related methodological approaches were adopted to investigate the issues identified. First, a questionnaire survey of parents of disabled children living in Torbay was distributed through the school in Torbay which specialises in educating children with severe disabilities (Mayfield School). Permission and appropriate approval was obtained from the Head Teacher and a questionnaire was distributed to the parents of all 130 pupils attending the school via each child's 'book bag' (19 October, 2012, with a reminder on 6 November, 2012). It was later established that 101 of these pupils matched the disability criteria for this study. The questionnaire comprised five open-ended and twelve closed questions, relating to the positive and negative impacts of their current accommodation on day-to-day routines and activities, together with the overall satisfaction with their current housing. A total of 
34 completed questionnaires were returned, representing a response rate of 33.7 per cent.

Second, as a supplement to the questionnaire survey, a focus group was undertaken with parents recruited from the survey to explore house design and experiences in greater depth. Five respondents represented a cross-section of ages, marital statuses, sexes, employment status and tenure mix. The discussion was split into two parts: the first thinking about and discussing the worst features of house design and the second focusing on the best features of house design within the context of severe disability and its management.

Third, a short questionnaire survey was undertaken of the views of some of the major house builders in Torbay regarding the barriers preventing inclusive home construction. A questionnaire survey was favoured over interviews because of the likelihood of a higher response rate as potential respondents could complete the survey within their busy working schedule. Using Torbay Council's Planning website to establish contact details, developers who had commenced planning permissions for one hundred residential units or more in Torbay over the last ten years were targeted. The sample included nine companies, who had built 2,476 units of accommodation in Torbay over the last ten years (2003-2012) (see Table 2). Enquiries were made with each company to establish the most appropriate member of their staff to complete the questionnaire, which in most cases was the person with responsibility within their organisation for completing Government and National House Builders surveys. The questionnaire asked about the perceived barriers to housing delivery, internal design, and awareness of disability and design. Two reminder telephone calls were made 
during the four-week survey period, which yielded five responses (55.5 per cent response rate).

Fourth, a total of eight professionals from key areas in Torbay Council's development control, planning policy, housing and children's services departments were interviewed about their experience of policy formulation, affordable housing allocation and child service provisions. Permission to carry out the study was granted by the Chief Executive for Spatial Planning of Torbay Council. The interviews focused on negotiations with developers and expected reactions from developers; the evidence base for disability; barriers to the creation of housing supply policy for inclusive homes; current policy effectiveness; and housing needs assessment. The results from the parent and developer surveys were shared with the interviewees as the basis for further discussion ${ }^{2}$. Despite the small samples, the responses offered a rich and well-informed testimony.

\section{Results}

Survey and focus group with families with disabled children

Characteristics of sample: The housing characteristics of the respondents in the sample illustrate that over three-quarters lived in larger housing types (namely, semidetached or detached properties). About two-fifths were owner occupiers, leaving

\footnotetext{
${ }^{2}$ The positionality of the main researcher should be noted. As a parent to a disabled child, the relevance of the subject matter was of great personal and emotional immediacy. A range of personal contacts within the support mechanisms in this area therefore facilitated the research. For example, the distribution of the questionnaire survey to parents through Mayfield School was facilitated by the researcher's child having attended the school in the past. In addition, at the time of the study, the main researcher was an employee of Torbay Council and so had direct access to local government planning officers. The researcher's professional relationship with council officers meant that none declined to be interviewed, and they were prepared to engage more fully than might have been the case if contacted by an unknown researcher. While the effect of these influences on the depth and outcome of the research is difficult to judge, it seems likely to have led to enhanced insights being obtained.
} 
over half renting from the private sector or as social tenants. About three-quarters of households contained four persons (husband, wife and two children), with the remaining one-quarter of households containing between five and eight persons. In most cases, households comprised both parents living together, although three respondents were single-parent households.

Nearly three-fifths of the sample had a child with one disability, with a further twofifths having a child with two or more diagnoses. By far the most common disability experienced was autism (11), followed by cerebral palsy (8), global developmental delay (7), Down's syndrome (6) and epilepsy (6). There were five other conditions affecting a smaller number of families (see Figure 1). Not surprisingly, the respondents' experience and satisfaction with their residential environment, together with their identification of the features of an 'ideal' home, were highly inter-related.

Experience of current accommodation: The most common negative responses about current accommodation was that it was too small for the needs of a family with a disabled child or children (14), needed adaptation (10), had poor access (9), lacked adequate storage space particularly for the additional paraphernalia required for the care of disabled children (9), possessed insufficient sound insulation (7) and inappropriate flooring (6). The most common positive responses concerned level access (14), a separate bathroom for the disabled child (13), the possession of an enclosed safe garden (11), comfortable accommodation (10), and security (9) (see Table 3). The appearance of some features in both lists, such as level access, sufficient living and storage space, and security indicates the importance of these design features for families with severely disabled children. Although it is 
acknowledged that a generalised vague aspiration to occupy more spacious homes exists in the wider population, for families with disabled children, the room to manoeuvre bulky equipment and to store items was seen by respondents as an acute and essential need. Households with severely disabled children tended to favour the older properties, which possessed more generous space standards, although it was ultimately housing affordability that constrained choice for the families:

'We looked at modern homes, but the rooms were just too small [for our special needs], so we went for a 1960s house instead'.

'The room sizes in our home and ones we have viewed are just too small [to accommodate us acceptably]. The houses with bigger rooms are too expensive'.

The effects of these broad deficiencies on the care of the disabled child were exemplified in the insights provided by the focus group discussions. The lack of space ultimately impinged on the quality of the medical care possible for the disabled child, especially in terms of the convenience and hygiene of bathroom spaces and the storage of equipment. Mainstream housing design, such as stairs, presented severe mobility constraints and risks for the disabled child and their carers. It is clear that all of these deficiencies affected other members of family as much as they did the disabled child. A few selected comments noted:

'Our bathroom and sinks are just too small - this makes changing pads very messy'.

'We have to put equipment in the porch and corridors, which makes it harder to move around the house and causes damage'.

'Our carpets are ruined. We need an easier way to clean floor coverings'.

'X is a heavy strong child and, as I'm getting older, I'm finding it harder to manage him up the stairs and it's dangerous'. 
Not surprisingly, the effect of these circumstances for other family members was stress, which was mentioned by over half of the respondents. The source of such stress was multiple, and included the need for constant vigilance and monitoring (13), the effects of disturbed sleep (12), inadequate living conditions (11), and high utility bills (4). Contributions to the focus group discussion highlighted the relentless nature of the vigilance required:

'We are constantly following $X$ around the house because of all the sharp corners which he will walk into or the windows which have internal sills which he sits on and then strikes the glass with his hands'.

'We cannot relax in our own home because it's unsafe for her: we are always on alert, it's relentless'.

'I wish we had under-floor heating as X pulls and kicks our radiators. I'm worried they will burst and harm him'.

The focus group also revealed that an additional dimension of the related stress was concerns about the effects of any disturbance on neighbours:

'He squeals and bangs on the wall at all hours, waking us and probably our neighbours most nights - this is so stressful'.

'We're stressed out because we worry about what our neighbours think when X has a 'melt down' and the noises he makes'.

By far the highest cause of stress, however, was the lack of personal space for all members of the family (14); the effects of overcrowding were expressed in rather understated terms: 
'We are 'on top' of each other and this is stressful'.

'We have no place to have quiet time'.

For a small number of respondents, these circumstances had contributed significantly to their own poor health (3). These outcomes represent the ultimate consequences of broader structural influences, such as longstanding planning principles and the dominant model of housing construction, which restrict the housing choices of groups in society that have different requirements from the norm.

Satisfaction with current housing accommodation: Half of the sample was not satisfied with their current accommodation and, of these, over three-quarters wished to move. All types of housing and tenure were represented in these dissatisfied groups, although those in detached and semi-detached houses experienced higher levels of satisfaction than occupants living in flats. Tenants (social and private) were the least satisfied group and were more likely to aspire to 'better' accommodation than the owner occupiers in the sample. Families with children diagnosed with trisomy, motor sensory neuropathy, autism, cerebral palsy and Attention Deficit Hyperactivity Disorder (ADHD) were the least satisfied with their current accommodation (see Table 4).

This high level of dissatisfaction with current accommodation was reflected in the number of families attempting to improve their housing conditions through adaptation of the property. Ten respondents had undertaken structural adaptations of their property, with a further ten making non-structural adaptations. The highest levels of structural adaptations were amongst families with a child diagnosed with motor 
sensory neuropathy, epilepsy, global developmental delay, cerebral palsy and ADHD. The proportion of non-structural adaptations were at a lower magnitude across all diagnoses, except for Williams syndrome, motor sensory neuropathy and ADHD (see Table 5). Only just over one-quarter were aware of the local Torbay Council's adaptation service, which provides support and advice about structural and nonstructural modifications to properties for these groups. Many families had therefore undertaken property adaptations without awareness or the support of this service (two-fifths of those undertaking structural and nearly three-quarters of those undertaking non-structural changes). One respondent in the focus group indicated that, because of the struggle in obtaining an adaptation, they felt tied to their current dwelling which acted indirectly as a constraint on their residential mobility: 'It took a long time for us to get an adaptation and so if we moved we would probably have to start all over again: better the devil you know'.

Features of an 'ideal' home for a disabled child: Although the small sample size precluded the development of a completely comprehensive model of the housing design requirements for different diagnoses, a number of general features of an 'ideal' home for families with a severely disabled child were observed (see Table 6). First, above all other features, the importance of an enclosed garden space to allow meaningful interaction with other members of the family and to contribute to the child's quality of life was mentioned by nearly half of the families across the different diagnoses. One respondent noted: 'It's very confined where I am so a garden to play sensory games would be lovely for X'. Second, all conditions (with more than three responses) emphasised the value of level access across the layout of the house to ease for movement of the disabled child and any associated equipment. Third, high 
importance was attached to the demands for more space, which covered an array of requirements from larger room sizes with open-plan layouts to wet rooms; drying rooms; spare rooms for sensory, physiotherapy, soft play or time-outs; storage areas and lockable cupboards; and independent living spaces for the rest of the family.

Reflecting the experiences of caring for a disabled child discussed earlier in the paper, a number of the design features reflected concern for safety. Non-structural adaptations to reduce the risk of harm to the child, such as higher electric points and switches, non-tamper light switches, automatic water taps and padded walls for the child's bedroom, were also highlighted. Under-floor heating in all rooms was mentioned by a number of respondents to reduce the risk of burning and scalding from standard wall-mounted radiators. Other suggestions were designed to improve the convenience of running the property, such as soft-tiled floors for easy cleaning, especially in dining areas, and closed-circuit television monitoring in all rooms with hand-held monitors to provide surveillance of the disabled child at all times. Another involved the location of bedrooms on the north-facing side of a house to prevent children from waking up early in the summer months and so allowing the rest of the family more time to sleep.

While such adaptations would benefit most diagnoses, each condition has slightly different requirements (see Table 6). Children diagnosed with autism and cerebral palsy, as two of the better represented categories in the survey for example, would benefit from different types of adaptations in house design. While the care for autism might be better accommodated in houses with enclosed gardens, level access (bungalows) and soundproof rooms, the care of cerebral palsy, while also needing 
level access, required extra space for care rooms and wet rooms as well as flexibility in room layout. The care of children with GDD required sound proof rooms, flexibility in room layout and extra care rooms, while the care of children with Down's syndrome required more storage space.

Perhaps unsurprisingly, over three-quarters of families with a disabled child were in agreement regarding provision for their needs being stipulated in planning policy, although five did not know and three disagreed. Over two-thirds felt that such a policy should not concentrate housing for the disabled in single-site clusters, which might offer benefits for the provision of support services and mutual self-help. There was instead a preference to be integrated as part of the community, because of a fear that stigma and prejudices might emerge through the potential 'ghettoisation' of this group. The results of both the survey and focus group demonstrated that there is a clear demand for more inclusive residential accommodation for families with disabled children.

\section{Survey of developers and planners}

All five developers and seven of eight planners interviewed confirmed emphatically that there is an awareness of the problems caused by mainstream housing design to disabled groups, especially families with disabled children. A developer admitted that 'we know that standardised housing designs do cause problems for people with disabilities', while a planner noted that 'it has been known for years that there is a need and a market [for inclusive homes]'. However, there appear to be institutional processes or attitudes preventing these inclusive needs from being met. Several 
possible explanations were revealed from the responses of both developers and planners in the survey.

First, the issue of inclusive housing for disabled groups did not appear to be a priority for either developers or planners. The main concern for developers was managing the risk of their financial investment in new housing developments before returns were secured. Developers worked towards the local authority's minimum room sizes in order to maximise density and thus generate a gross profit from housing development sites. Gross profits of between 20 and 30 per cent were required by developers over the predicted sales period. A developer stated that: 'Our company likes the current plan-led system and the National Planning Policy Framework because it does not increase the availability of land for new development or increase plot and room sizes, making development a viable proposition'.

Only two of the five developers included in the survey had been consulted about the design requirements of the disabled by any public authority (in this case, a social housing company and a local authority affordable housing manager). Amongst some of the planners, there was an assumption that if a family-sized home was not adequate, then the family would adapt it accordingly and pay for the work with a Disabilities Funding Grant (a means-tested grant for adaptation work to property) or their own resources (DCLG, 2009). All planning professionals felt that the 'Homes for Life' sustainable standard, by making properties capable of adaptation and extension as needs arose, appeared to dampen recognition that other interventions should be made, such as planning conditions or new tenure types. The system in the UK is thus 
geared to adaptation at the post-build stage and this feature redistributes responsibility onto already stretched families.

Second, perhaps as a consequence of the first point, there had been far too little progress towards establishing an evidence base for disabled housing needs in the area. As one planner stated: 'We have carried out some work around the needs of the elderly and mobility, but none on specific housing supply and design for the severely disabled... we have no evidence base in this area'. Planners in Torbay had tended to give more attention to the housing needs of the elderly (sheltered accommodation and care homes) rather than undertake more systematic research into the specific housing supply and design issues for families with severely disabled children. Another planner highlighted the problem of not having clear guidance from central government over housing needs assessments in that: '...every other authority in the region is using a number of different methodologies to assess the need... so there is little by way of a joined-up approach or evidence base'. As a consequence, the planners lacked an evidence base, and so did not possess the confidence to impose planning conditions or refuse planning applications on the basis of provision for disabled groups. There was a fear that refusals without evidence-based policy would result in appeals and, in all probability, the award of costs against the Council. One of the developers noted: 'Provisions of all types of housing is slow and a protracted process. Greater reliance upon the evidence base of need and demand is required'.

Third, despite the potential for disagreement between the planners and developers about how to deliver inclusive housing accommodation for families with severely disabled children, there was a surprising degree of consensus. Yet there appeared to 
be little communication and collaboration between the professional groups responsible for the planning and development of housing for disabled groups to facilitate real change in housing delivery. A planner stated: 'We agree that if an evidence-based need had been identified for a particular form of housing, then we (the local planning authority) should be able to prescribe provisions to meet that need'. Planners felt that new planning regulations would be required, because 'developers would be less happy to provide inclusive homes without imposing new planning regulations'. These regulations would have to be very prescriptive by requiring, for example, '... a two per cent bespoke home provision in every fifty new homes' (ie. one in 50). Such mechanisms might prove to be rather too crude to obtain a housing stock comprising sufficient numbers and in the right locations, irrespective of whether the restrictions offered a commercial proposition for the developers. It had been the experience of half of the local authority officers questioned that some resistance to existing housing policy, mainly based on the cost implications/profit reduction of improved space standards, had been made by developers in the past. Indeed, one developer commented: 'We have incurred extra cost and had to delay completion of projects because of new changes to Part M Building Control regulations'.

Nevertheless, all but one of the developers felt that local authorities should impose a policy to provide a minimum percentage of inclusive accommodation as long as there was a proven need and viable market. One developer stated that '...they thought it would be the right thing to do'. Half of the developers thought that the minimum figure should be between 5-10 per cent, with the other half placing the figure at 10-20 per cent. Developers were not necessarily averse to responding to the needs of disabled people and to supply accommodation with a higher space standards. One 
developer suggested that 'any extra cost might not necessarily be passed onto the market... sale prices of bespoke homes would be reduced because land values for such properties would be lower than that for the general residential market'. This finding points to the importance of improved communication to resolve any misunderstandings and misconceptions between the key stakeholders. The implications for developer costs and profit margins might be minimal because, in most cases, disabled groups required different rather than additional features in their housing specifications, such as heating, flooring and socket heights. These specifications did not necessarily impose additional costs, so long as these features could be incorporated at the construction stage (Imrie and Hall, 2001). Extra expenditure might be absorbed through a reduced profit margin. These issues require further investigation in future research.

\section{Discussion and Conclusion}

The original contribution of this paper has been to investigate the issues of housing design and delivery for families with disabled children from the perspectives of three different stakeholders within the same geographical region. While there is recognition of a 'problem', structural constraints imposed by the economic model of housing construction, the uncertainties within the development and planning process, and the lack of communication between stakeholders create very real barriers to the satisfactory resolution of housing design for families experiencing difficulties. In many respects, the development and planning process situates the provision of housing suitable for disabled groups within the 'medical' model of disability, whereby standard designs can be adapted to ameliorate physical and cognitive impediments. A shift to a 'social' model, where disabilities can be ameliorated through more inclusive 
design incorporated at the construction stage, requires a substantial transformation of the business model, regulation and stakeholder communication/collaboration within the planning and development process.

The speculative model of housing development in the UK, driven by the need for developers to deliver profitable schemes through volume construction, maximised densities and standardised design, can be argued to discriminate against disabled groups, such as families with severely disabled children. Building controls for disabled needs are not necessarily a complete solution as they can establish a 'least acceptable solution' through minimum compliance, define disability in narrow terms of 'visitability' and wheelchair users rather than a broader range of objectives, and focus on disability in adults rather than children.

The results of this study in Torbay have illustrated the experiential reality of families with a disabled child living in a mainstream designed property. Issues related to the importance of level access, sufficient living and storage space, and adequate sound proofing indicated the deficiencies of standard housing design for this group. As a result, the effect on all members of the family was evident in the level of stress experienced in the home environment through having to contend with the need for constant vigilance and monitoring, disturbed sleep, a lack of personal space, and high utility bills. In some cases, the stress caused ill-health in the other members of the family, especially parents, and so arguably rendered the properties as 'unhealthy' (Oldman and Beresford, 2010). About half of the sample was not satisfied with their current accommodation and, of these, over three-quarters aspired to move. It is clear that disability can be made worse by mainstream housing provision, and that more 
inclusive provision can render the children and their families 'more able' and better equipped to deal with the disabilities they face. Inclusive housing has the potential to reduce effective disability and improve the quality of life of its occupants. Such a shift in housing provision would embrace the social model of disability.

Although a much larger and representative survey would be required to verify associations, it is possible to identify, in a preliminary way, the design features of a house that would ameliorate some of the care issues affecting the diagnoses. For example, strong commonality was evident for enclosed garden spaces, level access across the layout of the house, and extra space to accommodate a range of needs. Particular diagnoses require specific features, such as sound proof rooms for autism and GDD, whereas a greater emphasis on higher space standards was needed for the care of cerebral palsy and Down's syndrome.

Although both developers and planners recognised the issues of mainstream housing for families with disabled children, there appeared to be institutional processes and attitudes that had established inertia and inaction over this issue. Developers tended to be driven by the commercial imperative to realise a $20-30$ per cent gross profit on housing developments and planners assumed that any deficiencies in the design of family homes would be corrected by post-build adaptation. Through a lack of an evidence base for disabled needs, planners did not possess the confidence to impose conditions or obligations or refuse planning applications to cater for these groups (without incurring costs against the Council at appeal). As long as a proven need or viable market could be demonstrated, developers were willing to provide a minimum percentage of inclusive accommodation (with most offering 5-20 per cent). At the 
heart of the issue, however, remains the small space standards in the UK, which constrains the flexibility of houses to accommodate the various needs and demands of the occupants.

However, what does seem to be apparent from this study is that the current development and planning approach to housing provision for disabled groups in the UK is markedly dysfunctional and certainly not 'joined up'. The scope for improved communication and collaboration to resolve misunderstandings and misconceptions between planners, developers and families is substantial. The housing needs of families with disabled children must be fully understood so that properties, despite their generally inadequate provision of overall floor space in the UK, offer much more of what is needed rather than what planners and developers think is needed. Such a shift in approach would more fully embrace the 'collaborative' or 'communicative' turn in planning encapsulated in the emergence of spatial planning and localism (Healey, 2005). Developers and planners might have to become more willing to accept subjective, qualitative and experiential data as part of the evidence base for policies and actions. Such an emphasis would be contrary to the underlying and fundamental reality of economic viability for developers.

One priority is the need for comparative investigations in other countries in order to pool ideas for both the design and delivery of more flexible and suitable homes for families with disabled children. Another priority is to establish a realistic and viable proportion of new developments that should be capable of accommodating disabled children based on cost/profit margin implications. A formal mechanism to ensure ongoing dialogue and collaboration is required to ensure that current issues are 
addressed and that the future is more enlightened. While in the short-term there is little option but to retrofit homes currently occupied by families with disabled children, the ultimate long-term goal should be to increase the proportion of newly built dwellings that are designed with disabled needs included. Eventually, the housing stock could then have sufficient units to offer families with these needs. Nevertheless, the process of matching demand (ie. families) to supply (ie. the most suitable property) remains a challenge within an essentially supply-led system. Arguably, however, this planning challenge might be less daunting if this debate was broadened to encompass the quality of spaces in new homes more generally (CABE, 2010; RIBA, 2011; DCLG, 2013), including the case for the (re)introduction of minimum space standards, such as the London Housing Design Guide (Mayor of London, 2010). Such standards would contribute to residential environments better suited to the household needs of the twenty-first century, but balanced against the implications for land supply and affordability as well as redefining long-standing policies for urban encroachment and the protection of the countryside. 


\section{References}

Barlow, J., \& Ozaki R. (2003) Achieving 'customer focus' in private housebuilding: current practice and lessons from other industries, Housing Studies, 18 (1), pp.87-101. doi: 10.1080/0267303032000076858.

Beresford, B. (2006) Housing and disabled children: a review of policy levers and opportunities, (York: University of York: Social Policy Research Unit).

Beresford, B., \& Rhodes D. (2008) Housing and disabled children: Round-up, (London: Joseph Rowntree Foundation).

Beresford, B., \& Oldman C. (2010) Home, Sick Home: Using the Housing Experiences of Disabled Children to suggest a new theoretical framework, Housing Studies, 15, pp.429-442. doi: 10.1080/02673030050009267.

Burns, N. (2004) Negotiating difference: disabled people's experiences of housebuilders, Housing Studies, 19 (5), pp.765-780. doi: 10.1080/0267303042000249198.

Care Quality Commission (2012) Health Care for Disabled Children and young people: A review of how the health care needs of disabled children and young people are met by the commissioners and providers of health care in England (London: Care Quality Commission).

Clarkson, J. and Coleman, R. (2010) Inclusive design, Journal of Engineering Design, 21 (2-3), pp.127-129. doi: 10.1080/09544821003693689.

Commission for Architecture and the Built Environment (2010) Improving the quality of new housing: technical background paper, (London: CABE).

Department for Communities and Local Government (2009) Disabled Facilities Grant, (London: DCLG).

Department for Communities and Local Government (2013) Housing Standards Review: Consultation, (London: DCLG).

FTI Consulting (2012) Understanding supply constraints in the housing market, Report prepared for SHELTER, (London: FTI Consulting).

Gallent, N., Madeddu, M. and Mace, A. (2010) Internal housing space standards in Italy and England, Progress in Planning, 74, pp.1-52. doi:10.1016/j.progress.2010.04.001.

Gathorne-Hardy, F. (1999) Accommodating difference: social justice, disability and the design of affordable housing, in Butler, R. and Parr, H. (Eds.) Mind and Body Spaces: geographies of illness, impairment and disability, Routledge, London, pp.240-255. 
Gleeson, B. (1999) Can technology overcome the disabling city?, in Butler, R. and Parr, H. (Eds.) Mind and Body Spaces: geographies of illness, impairment and disability, Routledge, London, pp.98-118.

Harrison, M. (2004) Defining housing quality and environment: disability, standards and social factors, Housing Studies, 19 (5), pp.691-708. doi: 10.1080/0267303042000249152.

HATC Limited (2006) Housing Space Standards for The Greater London Authority, (Ilkley: HATC Limited). Available legacy.london.gov.uk/mayor/planning/.../spacestandards.pdf. [Accessed 28 December 2012].

Healey, P. (2005) Collaborative Planning: Shaping Places in Fragmented Societies, Second Edition, (Basingstoke: Palgrave Macmillan).

Homes and Communities Agency (2012) Non-mainstream housing design guidance, (London: Homes and Communities Agency).

Hooper, A. (2002) Consumer housing preferences in a market context, in: K. Barlett, M. Potter, J. Meikle, F. Duffy, R. Ozaki, J. Hakes, R. Young, \& A. Hooper (Eds) Consumer choice in housing: The beginnings of a house buyer revolt, (York: Joseph Rowntree Foundation), pp.101-120.

Hooper, A., \& Nicol, C. (1999) The design and planning of residential development: standard house types in the speculative housebuilding industry, Environment and Planning B, 26, pp.793-805. doi: 10.1068/b260793.

House of Commons Local Government and Local Communities Select Committee (2007) Coastal towns, Second Report of Session 2006-2007, HC351 (London: The Stationery Office Limited).

Imrie, R. (1996) Disability and the City (London: Sage).

Imrie, R. (2004a) Housing quality, disability and domesticity, Housing Studies, 19 (5), pp.685-690. doi: 10.1080/0267303042000249143

Imrie, R. (2004b) The role of the building regulations in achieving housing quality, Environment and Planning B, 31, pp. 419-437. doi: 10.1068/b3056.

Imrie, R. (2006) Independent lives and the relevance of lifetime homes, Disability and Society, 21 (4), pp.359-374. doi: 10.1080/09687590600680152.

Imrie, R. (2012) Universalism, universal design and equitable access to the built environment, Disability and Rehabilitation, 34 (10), pp.873-882. doi: 10.3109/09638288.2011.624250.

Imrie, R., \& Hall, P. (2001) An exploration of disability and the development process, Urban Studies, 38 (2), pp.333-350. doi: 10.1080/00420980124545. 
Madeddu, M., Gallent, N. \& Mace, A. (2015) Space in new homes: delivering functionality and liveability through regulation or design innovation?, Town Planning Review, 86 (1), 73-95. doi: 10.3828/tpr.2015.5.

Mayor of London (2010) London Housing Design Guide: Interim Edition, (London: London Development Agency).

Milner, J., \& Madigan, R. (2004) Regulation and innovation: rethinking 'inclusive' housing design, Housing Studies, $19 \quad$ (5), $\quad$ pp.727-744. doi:10.1080/0267303042000249170.

Nielsen, C.W. \& Ambrose, I. (1999) Lifetime adaptable housing in Europe, Technology and Disability, 10, pp.11-19.

Office of National Statistics (2012) The General Household Survey, (ONS, Fareham) www.statistics.gov.uk [Accessed 5 February 2013].

Oldman, C., \& Beresford, B. (2000) Home, Sick Home: Using the housing experiences of disabled children to suggest a new theoretical framework, Housing Studies, 15 (3), pp.429-442. doi: 10.1080/02673030050009267.

Pyer, M., Horton, J., Ticker, F., Ryan, S. \& Kraftl, P. (2010) Children, young people and 'disability': challenging children's geographies?, Children's Geographies, 8 (1), 1-8. doi: 10.1080/14733280903500059.

Rickey, B., \& Houghton, J. (2009) Solving the riddle of the sands: regenerating England's seaside towns, Journal of Urban Regeneration and Renewal, 3 (1), pp. 4655.

Royal Institute of British Architects (2011) The Case for Space: the size of England's new homes, (London: RIBA).

Torbay Council (2014) A Landscape for success: The Plan for Torbay to 2032 and beyond (Submission draft), (Torquay: Torbay Council).

United Nations (2008) UN Convention on the Human Rights of Persons with Disabilities, Articles $19 \& 28$, www.un.org/disabilities/default.asp?id=259 [Accessed 5 February 2013].

Williams, K. (2009) Space per person in the UK: A review of densities, trends, experiences and optimum levels, Land Use Policy, 26, pp.S83-S92. doi: 10.1016/j.landuse.pol.2009.08.024.

Young, I. (1990) Justice and the politics of difference, (Princeton: Princeton University Press). 


\section{List of Tables}

Table 1. Implications of mainstream housing design on families with children with severe physical and cognitive impairments

Table 2. The major house builders in Torbay, 2002-2012

Table 3. Positive and negative features of current accommodation as perceived by families with a severely disabled child $(n=34)$

Table 4. Satisfaction with current residential accommodation by child diagnosis (absolute value with percentage in brackets)

Table 5. Adaptations to current residential accommodation by child diagnosis (absolute value with percentage in brackets)

Table 6. Perceptions of desired features of an 'ideal' home for families with a severely disabled child (based on selection of up to three priorities, $\mathrm{n}=34$ )

\section{List of Figures}

Figure 1. Diagnosis of severely disabled children in the Torbay sample. 


\section{Table 1. Implications of mainstream housing design on families with children with severe physical and cognitive impairments}

\begin{tabular}{|c|c|c|}
\hline Diagnosis & Outline of condition & $\begin{array}{l}\text { Special housing design } \\
\text { considerations for condition }\end{array}$ \\
\hline Autism & $\begin{array}{l}\text { Difficulties with social interaction, } \\
\text { impaired language and communication } \\
\text { skills and unusual patterns of thought } \\
\text { and physical behaviour }\end{array}$ & $\begin{array}{l}\text { High space standards; simple internal } \\
\text { layout with each space having a distinct } \\
\text { function; plenty of storage; use of daylight } \\
\text { and neutral colours to control stress; sound } \\
\text { proofing between adjacent rooms and } \\
\text { dwellings; robust fixtures, fittings and } \\
\text { finishes; access to outdoor spaces. }\end{array}$ \\
\hline $\begin{array}{l}\text { Williams } \\
\text { Syndrome }\end{array}$ & $\begin{array}{l}\text { Genetic condition characterised by } \\
\text { cardiovascular disease, development } \\
\text { delays and cognitive impairments }\end{array}$ & $\begin{array}{l}\text { Tend to have anxious personalities so may } \\
\text { be fearful of heights and negotiating stairs, } \\
\text { and have eating, sleeping and toilet } \\
\text { problems. Can also be hypersensitive to } \\
\text { sound. }\end{array}$ \\
\hline Cerebral Palsy & $\begin{array}{l}\text { Number of neurological conditions that } \\
\text { affects a child's movement and co- } \\
\text { ordination, often with other conditions } \\
\text { such as epilepsy, incontinence and } \\
\text { visual and hearing impairment }\end{array}$ & $\begin{array}{l}\text { Higher space standards for wheelchair } \\
\text { access. Adapted bathrooms and toilets. } \\
\text { Easy access to outside. Equipment for } \\
\text { mobility and lifting: wide doorways and } \\
\text { hallways, ramps, hoists or lifts instead of } \\
\text { steps. Switches and sockets in easy reach. }\end{array}$ \\
\hline $\begin{array}{l}\text { Down's } \\
\text { Syndrome }\end{array}$ & $\begin{array}{l}\text { Genetic condition causing cognitive } \\
\text { impairments and a characteristic range } \\
\text { of physical features }\end{array}$ & $\begin{array}{l}\text { Emphasis on safety and simple layout. } \\
\text { Supportive space for carer(s). }\end{array}$ \\
\hline $\begin{array}{l}\text { Global } \\
\text { Developmental } \\
\text { Delay }\end{array}$ & $\begin{array}{l}\text { Children who have not reached two or } \\
\text { more milestones in all areas of } \\
\text { development (motor skills, speech and } \\
\text { language, cognitive skills, social and } \\
\text { emotional skills) }\end{array}$ & Safety gates \\
\hline $\begin{array}{l}\text { Motor Sensory } \\
\text { Neuropathy }\end{array}$ & $\begin{array}{l}\text { Heterogeneous group of inherited } \\
\text { neuromuscular disorders involving } \\
\text { progressive deterioration of nerve cells } \\
\text { causing fatigue, pain, lack of balance } \\
\text { and sight and hearing problems }\end{array}$ & $\begin{array}{l}\text { Need for aids designed to overcome } \\
\text { specific disability problems. Regular } \\
\text { physical, occupational and speech therapy. } \\
\text { Space for equipment (eg. Positive pressure } \\
\text { ventilation machines). }\end{array}$ \\
\hline Epilepsy & $\begin{array}{l}\text { Condition that affects the brain and } \\
\text { causes repeated seizures, known as fits }\end{array}$ & $\begin{array}{l}\text { Measures to improve safety in the home to } \\
\text { reduce risk of injury in terms of non-slip } \\
\text { flooring, protective covers on furniture, } \\
\text { use of safety glass, radiator and pipe } \\
\text { covers and fireguards. }\end{array}$ \\
\hline $\begin{array}{l}\text { Attention Deficit } \\
\text { Hyperactivity } \\
\text { Disorder (ADHD) }\end{array}$ & $\begin{array}{l}\text { Behavioural symptoms that include } \\
\text { inattentiveness, hyperactivity and } \\
\text { impulsiveness, including learning } \\
\text { difficulties and sleep disorders }\end{array}$ & $\begin{array}{l}\text { Space to keep child occupied as well as } \\
\text { personal space for parents and/or carers. }\end{array}$ \\
\hline $\begin{array}{l}\text { Chromosome } \\
\text { deletion }\end{array}$ & $\begin{array}{l}\text { Disorder caused by deletion of a small } \\
\text { piece of chromosome producing } \\
\text { developmental delay and intellectual } \\
\text { disabilities }\end{array}$ & $\begin{array}{l}\text { Higher space standards for care and } \\
\text { treatment of child and supportive space for } \\
\text { carer. }\end{array}$ \\
\hline
\end{tabular}




\begin{tabular}{|l|l|l|}
\hline Trisomy & $\begin{array}{l}\text { Genetic condition which disrupts the } \\
\text { baby's normal course of } \\
\text { development. Only 5-10\% of babies } \\
\text { with this condition survive beyond one } \\
\text { year and will live with severe } \\
\text { disabilities, mental retardation, } \\
\text { development delay, seizures and } \\
\text { feeding difficulties. }\end{array}$ & $\begin{array}{l}\text { Higher space standards for care and } \\
\text { treatment of child and supportive space for } \\
\text { carer. }\end{array}$ \\
\hline
\end{tabular}

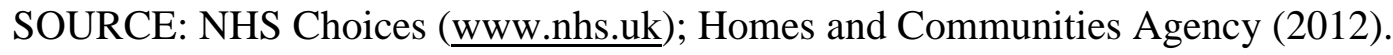

Table 2. The major house builders in Torbay, 2002-2012

\begin{tabular}{|l|c|}
\hline House builder & $\begin{array}{c}\text { Number of houses constructed in Torbay, } \\
\text { 2003-2013 }\end{array}$ \\
\hline Cavanna Group Limited & 975 \\
\hline Millwood Homes & 225 \\
\hline Northern Trust Company & 219 \\
\hline Linden Homes South West & 297 \\
\hline McCarthy and Stone & 174 \\
\hline Bloor Homes & 134 \\
\hline Sovereign Housing Association Limited & 186 \\
\hline Sanctuary Housing Group & 266 \\
\hline Total & 2,476 \\
\hline
\end{tabular}

SOURCE: Torbay Council Planning On-line 
Table 3. Positive and negative features of current accommodation as perceived by families with a severely disabled child $(n=34)$

\begin{tabular}{|l|l|}
\hline $\begin{array}{l}\text { Positive features of current } \\
\text { accommodation }\end{array}$ & $\begin{array}{l}\text { Negative features of current } \\
\text { accommodation }\end{array}$ \\
\hline Easy level access (14) & Too small (14) \\
\hline Child has own room (13) & Accommodation needs adaptation (10) \\
\hline Garden (11) & Lack of storage space (9) \\
\hline Comfortable accommodation (10) & Not level access (9) \\
\hline Accommodation is secure (9) & Poor sound insulation (7) \\
\hline Good landlord/neighbours (8) & Issues with flooring (6) \\
\hline Close to amenities (7) & No downstairs bathroom (4) \\
\hline Separate shower room (6) & No garden (3) \\
\hline House is detached (4) & Not close to amenities (2) \\
\hline
\end{tabular}

SOURCE: Questionnaire Survey of Parents $(n=34)$ 
Table 4. Satisfaction with current residential accommodation by child diagnosis (absolute value with percentage in brackets)

\begin{tabular}{|l|c|c|c|}
\hline Diagnosis & $\begin{array}{c}\text { Satisfied with } \\
\text { current } \\
\text { accommodation }\end{array}$ & $\begin{array}{c}\text { Not satisfied with } \\
\text { current } \\
\text { accommodation }\end{array}$ & Total \\
\hline Autism & $5(45.5)$ & $6(54.5)$ & 11 \\
\hline Williams Syndrome & $1(100)$ & 0 & 8 \\
\hline Cerebral Palsy & $4(50.0)$ & $4(50.0)$ & 7 \\
\hline Down's Syndrome & $4(66.7)$ & $2(33.3)$ & 6 \\
\hline $\begin{array}{l}\text { Global Sensory } \\
\text { Developmental Delay }\end{array}$ & $4(57.1)$ & $3(42.9)$ & 2 \\
\hline $\begin{array}{l}\text { Motor } \\
\text { Neuropathy }\end{array}$ & $4(66.7)$ & $2(33.3)$ & 3 \\
\hline $\begin{array}{l}\text { Epilepsy } \\
\text { Attention Deficit }\end{array}$ & $1(50.0)$ & $1(50.0)$ & 1 \\
\hline $\begin{array}{l}\text { Hyperactivity } \\
\text { Disorder(ADHD) }\end{array}$ & $2(66.7)$ & $1(33.3)$ & $1(100)$ \\
\hline $\begin{array}{l}\text { Chromosome } \\
\text { deletion }\end{array}$ & 0 & & $60)$ \\
\hline \begin{tabular}{l} 
Trisomy \\
\hline
\end{tabular} & 0 & $1(100)$ & 1 \\
\hline
\end{tabular}

SOURCE: Questionnaire Survey of Parents $(n=34)$ 
Table 5. Adaptations to current residential accommodation by child diagnosis (absolute value with percentage in brackets; Numbers do not necessarily add to 100 per cent as some families have undertaken both structural and nonstructural adaptations)

\begin{tabular}{|c|c|c|c|c|}
\hline Diagnosis & $\begin{array}{l}\text { Structural } \\
\text { adaptations }\end{array}$ & $\begin{array}{l}\text { Non-structural } \\
\text { adaptations }\end{array}$ & $\begin{array}{c}\text { No } \\
\text { adaptations } \\
\text { made }\end{array}$ & Total \\
\hline Autism & $2(18.2)$ & $3(27.3)$ & $7(63.6)$ & 11 \\
\hline Williams Syndrome & 0 & $1(100)$ & 0 & 1 \\
\hline Cerebral Palsy & $4(50.0)$ & $2(25.0)$ & $4(50.0)$ & 8 \\
\hline Down's Syndrome & 0 & $2(33.3)$ & $4(66.7)$ & 6 \\
\hline $\begin{array}{l}\text { Global } \\
\text { Developmental Delay }\end{array}$ & $4(57.1)$ & $2(28.6)$ & $3(42.9)$ & 7 \\
\hline $\begin{array}{ll}\text { Motor } & \text { Sensory } \\
\text { Neuropathy } & \\
\end{array}$ & $1(100)$ & $1(100)$ & 0 & 1 \\
\hline Epilepsy & $4(66.7)$ & $2(33.3)$ & $2(33.3)$ & 6 \\
\hline $\begin{array}{l}\text { Attention Deficit } \\
\text { Hyperactivity } \\
\text { Disorder (ADHD) }\end{array}$ & $1(50.0)$ & $2(100)$ & 0 & 2 \\
\hline $\begin{array}{l}\text { Chromosome } \\
\text { deletion }\end{array}$ & $1(33.3)$ & $1(33.3)$ & $1(33.3)$ & 3 \\
\hline Trisomy & 0 & 0 & $1(100.0)$ & 1 \\
\hline
\end{tabular}

SOURCE: Questionnaire Survey of Parents $(n=34)$ 
Table 6. Perceptions of desired features of an 'ideal' home for families with a severely disabled child (based on selection of up to three priorities per respondent, $n=34$ )

\begin{tabular}{|c|c|c|c|c|c|c|c|c|c|c|c|c|c|}
\hline \multirow[t]{2}{*}{ Diagnosis } & \multicolumn{3}{|c|}{ Size } & \multicolumn{6}{|c|}{ Internal modifications } & \multicolumn{4}{|c|}{ External space and location } \\
\hline & $\begin{array}{l}\text { Storage } \\
\text { space }\end{array}$ & $\begin{array}{l}\text { Extra } \\
\text { rooms }\end{array}$ & Bungalow & Wet room & $\begin{array}{l}\text { Room } \\
\text { layout }\end{array}$ & $\begin{array}{l}\text { Separate } \\
\text { living } \\
\text { spaces }\end{array}$ & $\begin{array}{c}\text { Sound } \\
\text { proofing }\end{array}$ & $\begin{array}{c}\text { Flexibility } \\
\text { of layout }\end{array}$ & $\begin{array}{l}\text { Drying } \\
\text { facilities }\end{array}$ & $\begin{array}{c}\text { Enclosed } \\
\text { garden }\end{array}$ & $\begin{array}{l}\text { Level } \\
\text { access }\end{array}$ & Safe area & $\begin{array}{r}\text { Close to } \\
\text { amenities }\end{array}$ \\
\hline Autism (n=11) & 1 & 1 & 4 & 1 & 2 & 2 & 4 & 1 & 2 & 5 & 0 & 1 & 1 \\
\hline Williams Syndrome $(\mathrm{n}=1)$ & 0 & 1 & 0 & 1 & 0 & 0 & 0 & 0 & 0 & 0 & 0 & 0 & 0 \\
\hline Cerebral Palsy (n=8) & 2 & 3 & 0 & 3 & 3 & 1 & 1 & 1 & 0 & 1 & 4 & 1 & 0 \\
\hline Down's Syndrome (n=6) & 3 & 1 & 3 & 0 & 1 & 0 & 0 & 0 & 0 & 3 & 4 & 1 & 1 \\
\hline $\begin{array}{l}\text { Global Developmental Delay } \\
(\mathrm{n}=7)\end{array}$ & 2 & 3 & 0 & 0 & 0 & 1 & 4 & 3 & 0 & 2 & 3 & 2 & 1 \\
\hline $\begin{array}{l}\text { Motor Sensory Neuropathy } \\
(\mathrm{n}=1)\end{array}$ & 1 & 0 & 0 & 1 & 0 & 1 & 0 & 0 & 0 & 0 & 0 & 0 & 0 \\
\hline Epilepsy (n=6) & 2 & 1 & 0 & 2 & 2 & 3 & 2 & 1 & 0 & 1 & 1 & 1 & 0 \\
\hline $\begin{array}{l}\text { Attention Deficit Hyperactivity } \\
\text { Disorder (ADHD) }(\mathrm{n}=2)\end{array}$ & 0 & 0 & 0 & 1 & 1 & 1 & 1 & 0 & 0 & 1 & 0 & 0 & 0 \\
\hline Chromosome deletion $(\mathrm{n}=3)$ & 2 & 0 & 0 & 0 & 0 & 0 & 0 & 0 & 1 & 1 & 1 & 1 & 0 \\
\hline Trisomy $(\mathrm{n}=1)$ & 0 & 0 & 0 & 0 & 0 & 0 & 1 & 0 & 0 & 1 & 1 & 0 & 0 \\
\hline TOTALS & 13 & 10 & 7 & 9 & 9 & 9 & 13 & 6 & 3 & 15 & 14 & 7 & 3 \\
\hline
\end{tabular}

SOURCE: Questionnaire Survey of Parents $(n=34)$ 


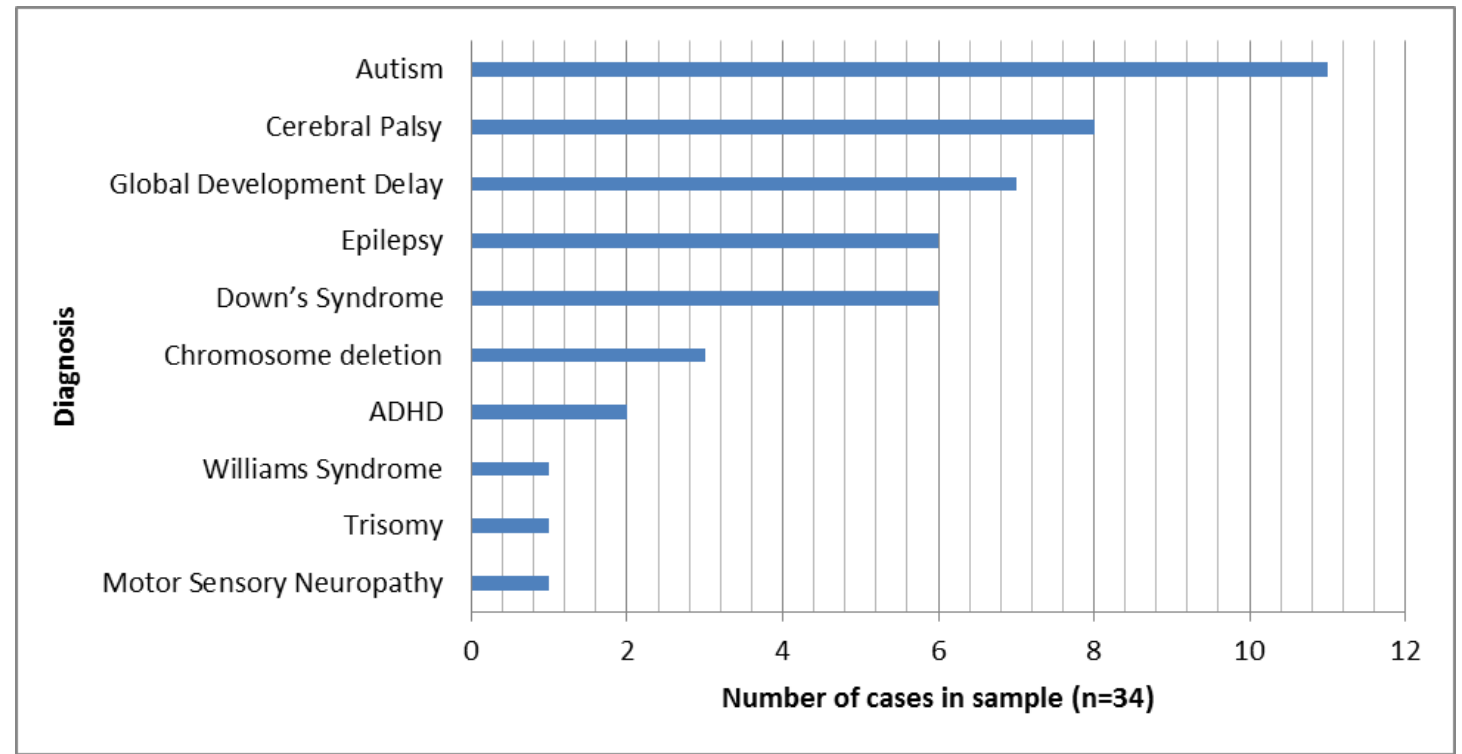

Figure 1. Diagnosis of severely disabled children in the Torbay sample. SOURCE: Questionnaire Survey of Parents $(n=34)$. 